\title{
Factors affecting women's empowerment on irrigation schemes in the North West Province, South Africa
}

\author{
S. S. Tekana \& O. I. Oladele \\ Department of Agricultural Economics and Extension, \\ North West University Mafikeng Campus, South Africa
}

\begin{abstract}
This study examines the impact of water-related policies on women's empowerment on irrigation schemes of the North West Province of South Africa. A simple random sampling technique was used to select 84 women on 5 irrigation schemes across the province. These irrigation schemes have been under different management styles over the recent past years. Data were collected on their demographics and empowerment using a modified Women Empowerment Agriculture Index developed by IFPRI. The indices covered women's access and control to physical, natural, social, financial, and human livelihood capital. The study also examined empowerment indices to show different areas where women are empowered and this included the use of income, $53 \%$ are disempowered, about $60.2 \%$ of women are disempowered in access to productive capital and access to credit, while about $50 \%$ are empowered in leadership and decision making. Significant determinants of empowerment were expenditure $(t=1.68)$ and drip irrigation type $(\mathrm{t}=1.71)$. The results highlighted different areas of intervention in order to ensure an adequate level of empowerment across the livelihood capital for women on irrigation schemes. It also highlights the need to promote women's participation in decision-making for water management and also suggests ways in which women's access to water can be improved through equitable development.
\end{abstract} Keywords: water security, women's empowerment, gender, water scarcity, livelihood capital. 


\section{Introduction}

Women play a pivotal role in agriculture, FAO [1] describes women in agricultural production in developing countries and noted that rural women manage households and pursue multiple livelihood strategies. Efforts towards ensuring food security have identified women farmers as key role players in many contexts and set-ups [1]. However, women's role in agriculture remains unrecognized in policy formulation and resource allocation [2]. A major intervention to improve agricultural productivity as the principal source of income for many households in rural areas of developing countries farmers is the introduction of irrigation to supplement water supply for farming activities. In the right environment and with correct practices irrigation provides more yield than rain-fed agriculture [3]. In South Africa, the term smallholder irrigation is mainly used when referring to irrigated agriculture practised by black people. South Africa has about 1.3 million ha under irrigation, of which 0.1 million ha is in the hands of smallholders [4]. Smallholders have been categorised into four groups, namely: farmers on irrigation schemes; independent irrigation farmers; community gardeners; home gardeners [5]. According to [4], smallholder irrigators in South Africa range between 200,000 and 250,000 ha but most of them are farming on small plots primarily to provide food for home consumption. Bruwer and Van Heerden [6] have documented the history of irrigation development in South Africa at large, identifying several eras, which are [7] linked to the economic development of the country. The different eras identified were characterised by specific policy and irrigation technology. These eras can be identified as follows: the first era of smallholder irrigation development occurred during the 19th century and can be referred to as the peasant era. The second era was referred to as the mission diversion scheme era, because it was associated with mission activity and the emergence of African peasantry [8]. Smallholder irrigation development was also private and the technology used (river diversion) was similar. The peasant and mission diversion scheme era was not very important and much of what was developed had ceased to function by the end of the 19th century.

The third period of smallholder irrigation development can be referred to as the independent homeland era. This period in smallholder irrigation development lasted from 1970 until the 1990s and was an integral part of the economic development of the homelands. The post-world war policy of Apartheid aimed at making black South Africans citizens of specific independent homelands. Spatially, these homelands had their origin in the "Bantu Areas". Each homeland was to cater for a particular cultural or language group. To give credence to the concept of independence, it became imperative that the economy of the different homelands improved, because without exception, they were islands of underdevelopment and poverty [9]. The establishment of new irrigation schemes with funding from South Africa, formed part of the economic development strategy of the homelands [10]. Agriculture was regarded as the main internal development opportunity for the homelands, because the resource base of these territories had remained essentially rural. 
The food plots provided homesteads that derived their livelihood from external sources, such as male-migration or old-age pensions, with an opportunity to enhance these livelihoods by producing food for home consumption. Management of these large schemes was centralised in the hands of specialised parastatals. The large schemes established during the independent homeland era were socially and economically very complex and proved costly to maintain. Social unrest and conflict during the late 1980s further affected their sustainability. Following the democratisation of South Africa in 1994, provincial governments decided to dismantle the agricultural homeland parastatals they had inherited. This decision particularly affected the large schemes, because they were the most complex and had been centrally managed from inception, resulting in exceptionally high levels of dependency among farmers [11]. Partial or total collapse of production followed this decision almost immediately [12].

\section{Water Act and irrigation policy in South Africa}

Much of South Africa's past water legislation was largely oriented towards irrigated commercial agriculture. The central principle in the previous water law was a link between the right to use water and the ownership of land adjacent to that water, i.e. the riparian principle and the prior appropriation system which is based on the principle of first in time, "first in right". In these systems, senior right holders have little incentive to invest in water-saving irrigation technology, because they are assured of a stable water supply. These systems were established at a time when water was plentiful, and the government wanted to provide an incentive for private development and innovation. However, water in many systems is now over appropriated, and better management is essential to make the best use of limited resources. The 1956 Water Act consolidated the system of riparian rights resulting in commercial white land-owning farmers having essentially unconstrained access to water. In commercial agriculture areas, irrigation boards that administrated the allocation of water were serving the needs of these farmers.

The position of the rural black and coloured people in the system of riparian rights is not difficult to imagine. They simply did not have sufficient (financial) capacity to get access to the administration for establishing water rights while private black land ownership was not allowed [13]. The fact that black people were concentrated in homelands with marginal water resources and infrastructure, and with informal or customary traditional land use rights contributed largely to the inequity [14]. Besides, government dams were, and still are, located in areas of urbanization and commercial estate farming, indicating that the rural population was forced de facto to turn to groundwater abstraction. Proper infrastructure to reach the groundwater resources in the former homelands was often lacking [15]. Under the apartheid governments, most black populations were not only deprived of access to water and land for irrigation purposes but also of adequate and clean water for domestic use [16].

In 1998, a new National Water Act replaced the old law after an extensive consultation process. In 1997, a new Water Services Act was established to 
address domestic water needs. The purpose of the National Water Act (NWA) is to ensure that the nation's water resources are managed in ways that take into account basic human needs of present and future generations, promote equitable access to water, redress past racial and gender discrimination, facilitate social and economic development, and protect aquatic and associated systems [17].

The system of allocation of water rights based upon the riparian principle was abandoned. It was now replaced by a system of permissible uses, general authorizations and licenses. The permissible use system is formulated in such a way that basic (mainly domestic) water users, indicated in a schedule attached to the act, are not subjected to the license and authorization system. The system of general authorizations allows the relevant authority to exonerate types of water uses, groups of persons, and certain parts of catchments at certain periods of time from legal restrictions or license application (section 39). Any other water use needs a license with a maximum duration of 40 years. After this period, the license has to be repealed (section 40). The relevant authority can attach further conditions or obligations to the licenses. The NWA sets out the new institutional framework for the management of water resources in South Africa. These water management institutions include catchment management agencies and water users associations [18].

With the dismantling of former dispensations and the adoption of a new democratic constitution, South Africa also adopted a new water policy, which culminated with the acceptance of a new national water Act - NWA (Act 36 of 1998). The NWA specifies that the government, as the public trustee of the nation's water resources, must act in the public interest to ensure that water is protected, used, developed, conserved, managed and controlled in a sustainable and equitable manner for the benefit of all persons [19]. According to [20], the success of smallholder irrigation development in South Africa has been limited compared with other countries in the sub-region. Schemes specifically designed and constructed for many farmers (smallholder schemes) have been planned in the same way as those for commercial farms with sophisticated infrastructure and field equipment expected to be shared between several farmers. In many places, this has resulted in unsustainable, poor performing small-scale irrigation schemes with a high level of dependency among the farmers and cultivators. IFAD [21] reports that many female farmers in irrigation are still poor, marginalized with no food security.

According to [22] Women Empowerment in Agricultural Index (WEAI) is a composite measurement tool that indicates women's control over critical parts of their lives in the house-hold, community, and economy. It helps in identifying women who are disempowered and understand how to increase autonomy and decision-making in key domains. The five domains are agricultural production, resources, income, leadership, and time and they comprise ten indicators. Each domain is weighted equally, as are each of the indicators within a domain. The main objective of the study is to examine the impact of smallholder irrigation farming on women's empowerment, food security and poverty status in the North West Province. 


\section{Materials and methods}

The study was conducted in the North West Province covering small holder irrigation farming in the Taung, Nyetse, Molatedi, Mayaeyane area. The province lies between 22 and 28 degrees longitude east of the Greenwich Meridian and between 25 and 28 degrees latitude south of the Equator [23]. The region is situated $1200 \mathrm{~mm}$ above sea level and has an annual rainfall of $430 \mathrm{~mm}$. The climate is very dry, especially in winter, and summers are hot with temperatures ranging from 16 to $38^{\circ} \mathrm{C}$. Agriculture plays an important role with approximately $60 \%$ of rural livelihood. The research design of the study is descriptive and quantitative. The total population of 120 women was identified during the recognisance survey, a simple random sampling technique of 84 women were selected. Data for this study were generated from primary sources based on the objectives of the study. An interview schedule was used to elicit information from the respondents. Data were analysed by using the Statistical Packages for Social Science (SPSS). The descriptive statistics such as frequency distribution, percentages, mean and standard deviation were used to describe the personal characteristics of the women farmers on the scheme. A linear regression model was used to isolate factors determining empowerment with particular reference to the effects of socio-economic characteristics; irrigation type and livelihood activities on the irrigation scheme.

\section{Results and discussion}

The results in Fig. 1 show the household characteristics, the largest age group ranging from 41 to 50 years accounts for $72 \%$. This confirms the proposition that the proportion of young people in agriculture is low. Akinbile et al. [24] stated that active participants in farming activities are between the ages of 40 and 50 years in South West Nigeria. Fig. 1 also indicates that $46.7 \%$ of farmers have a household size of 6-10 persons. Larson and Kanyangwa [25] argue that if the household size is small and is headed by a female, this could cause shortage of labour during the peak season and that also impacts on household income. According to [26] female-headed households tend to be small in size, have low incomes and are less likely to adapt to technology and this hinders agricultural production. Fig. 1 also shows that $42.2 \%$ of women in irrigation farming are married, $31.3 \%$ are single and $26.5 \%$ are widowed. This indicates that women, especially married women, do not often make decisions on their own as they have to consult their husbands, which could impact negatively on empowerment. Judd and Dulnuan [27] also asserted that due to socio-cultural factors women have little authority in decisions in agricultural production. The results in Fig. 1 indicate that $32.5 \%$ have a primary education while $26.5 \%$ have secondary and high school education, $11 \%$ have no formal schooling and only $3 \%$ have tertiary education. Education is important to farm production because of the rapid change in technology and the economic environment. The findings also indicated that $66.3 \%$ of women farmers have farming experience ranging from 1 to 10 
years, indicating that there are new entrants into farming, while only $1.2 \%$ indicates experience of more than 40 years. This result is similar to the findings of [28].

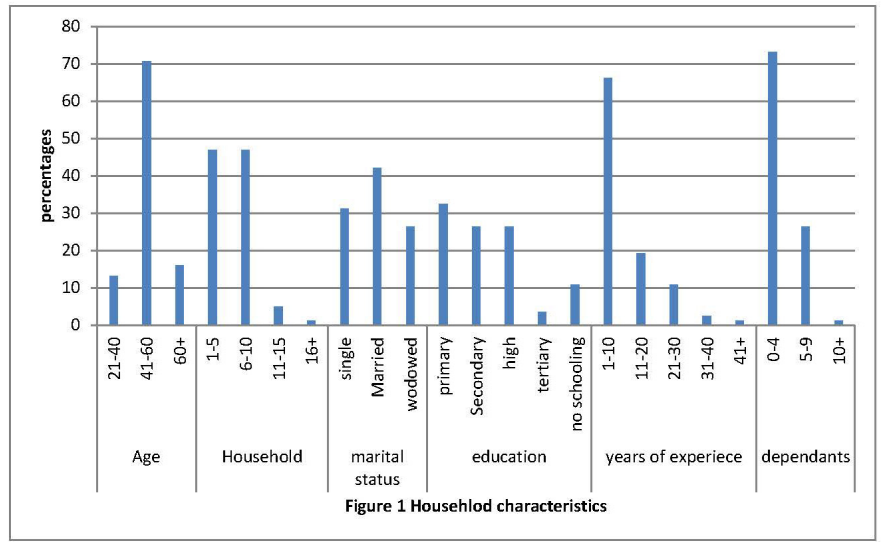

Figure 1: Household characteristics.

Table 1 shows access of women farmers to livelihood assets. Table 1 also shows that $84.3 \%$ of farmers obtain their credit from a relative but $62.75 \%$ of them indicated that it is not adequate. Seventy nine percent of farmers also indicated that banks are the other source of credit even though only $6 \%$ of farmers indicated that credit from the banks is adequate. Credit is important for farmers because it helps them to secure fertilizers, improved varieties of seed and other technologies on the farm. Inadequate finance can also prevent farmers from investing in new methods of crop production and irrigation [29]. Lack of access to credit is one factor that reduces women's efficiency and productivity. Machete [30] argued that one of the most critical problems threatening the viability of smallholder irrigation is the absence of credit. Access to credit needs collateral mostly in the form of land rights, which some farmers do not possess particularly women.

Table 1 shows that $68.7 \%$ of farmers indicated that they have received training. Extension service is important in boosting agricultural productivity and $62.7 \%$ of farmers reported to have received an extension service. With regard to skills training, $63.9 \%$ of women received training in equipment handling, soil management $(62.7 \%)$, water management $(56.6 \%)$, crop protection $(56.6 \%)$, and record keeping $(53 \%)$ while only $38.6 \%$ indicated that they were trained in financial management. Machete [30] argues that an understanding of financial management will generate a continuous flow of irrigation scheme profitability, liquidity and reducing risks and this will provide a basis of forward planning for farmers. With regard to access to physical capital, Table 1 indicates that $67.5 \%$ reported the availability of water canals. Fifty nine percent reported availability of road access, electricity availability $(72.3 \%)$, access to markets $(44.6 \%)$, storage facilities $(62.7 \%)$ and $39.8 \%$ of them have transport facilities to take their produce to the market. 
Table 1: Access to livelihood assets.

\begin{tabular}{|l|l|l|}
\hline Financial capital & Yes & No \\
\hline Access to credit from & & \\
\hline Banks & $66(79.5)$ & $17(20.5)$ \\
\hline Cooperatives & $68(81.9)$ & $15(18.1)$ \\
\hline Money lenders & $67(80.7)$ & $16(19.3)$ \\
\hline Relatives & $70(84.3)$ & $12(14.5)$ \\
\hline Personal savings & $65(78.3)$ & $18(21.7)$ \\
\hline Contractors & $52(62.7)$ & $31(37.2)$ \\
\hline Government subsidies & $51(61.4)$ & $32(38.5)$ \\
\hline Human capital & & \\
\hline Training & $57(68.7)$ & $26(31.3)$ \\
\hline Vocational training & $20(24.1)$ & $63(75.9)$ \\
\hline Extension service & $52(62.7)$ & $31(37.3)$ \\
\hline Skills training & & \\
\hline Record keeping & $44(53.0)$ & $39(47.0)$ \\
\hline Water management & $47(56.6)$ & $36(43.4)$ \\
\hline Equipment handling & $53(63.9)$ & $30(36.1)$ \\
\hline Financial management & $32(38.6)$ & $51(61.4)$ \\
\hline Soil management & $52(62.7)$ & $31(37.3)$ \\
\hline Crop protection & $47(56.6)$ & $36(43.4)$ \\
\hline Physical capital & & \\
\hline Transport & $33(39.8)$ & $50(60.2)$ \\
\hline Water supply & $56(67.5)$ & $27(32.5)$ \\
\hline Markets & $37(44.6)$ & $46(55.4)$ \\
\hline Road accessibility & $49(59.0)$ & $34(41.0)$ \\
\hline Electricity & $60(72.3)$ & $23(27.7)$ \\
\hline Storage & $52(62.7)$ & $31(37.3)$ \\
\hline & & \\
\hline
\end{tabular}

In this study a modified Women Empowerment in Agricultural Index (WEAI) was used because the questionnaire did not cover time budgeting. The empowerment indices covered in this study include the use of income, access to productive capital, access to credit, leadership roles and decision making. From the scoring of the empowerment indices, the mean was calculated for each of the indices and used as the cut-off point. Women with scores below the mean depict disempowerment while those above the mean indicate empowerment.

Use of Income in Table 2 indicates that $56 \%$ of women in terms of the control over the use of income are below the mean score of 16.80 , which implies that they are disempowered in the control of the use of income as an index of empowerment. According to [20], women tend to spend most of their income on basic household needs, such as household essentials, while men tend to retain more of the income they control for their personal use, such as buying alcohol, drinking and leisure. The study also indicated that, in certain parts of Uganda, such as Apac and Kumi, husbands are more likely than elsewhere to entrust the income to their wives, to prevent its misuse. But some men are afraid to do so, in case the women might be tempted to leave them. 
Access to Productive Capital in Table 2 indicates that the proportion of women below the mean (78.99) for access to productive capital as an index of empowerment is $60.2 \%$. This shows that women are disempowered in terms of their access to productive resources as an index of empowerment. Lopi [31] argued that, although policies aimed at creating enabling environments have been established in nearly all countries for women to access, own, control, and use and manage land for productive use, the actualization of such still remains a challenge. The gender approach of agencies and projects, as well as the local class and gender hierarchies, is also one of the causes of gender-related inequities in access to water resources in sub-Saharan Africa [32].

Access to Credit in Table 2 indicates that $60.2 \%$ of women in terms of access to credit are below the mean score of 113.56, showing that women are disempowered in terms of access to credit as an index of empowerment. IFPRI [22] ascertained that lack of collateral, low levels of education with a resultant lack of numeracy and access to information are factors contributing to the fact that $10 \%$ of agricultural credit in the SADC (16 countries of Southern Africa) region is accessed by women. In some instances, women need the consent of their spouses in order to access credit and this makes them lose confidence in themselves and become disempowered. It is thus important for women to have not only access to credit but also control over the use of the credit so that it is not diverted to male-dominated production systems, at the expense of women's productive activities.

Leadership Role in Table 2 indicates that $51.8 \%$ of women in terms of leadership roles are above the mean score of 43.98. This indicates that in terms of women engagement in leadership roles the difference is very marginal when compared with the mean score. This could be because of the fact that, due to unequal gender norms and relations, women have a lower socio-economic status, compared to their male counterparts, which limits their opportunities to access and participate in formal groups. World Bank [33] justifies the fact that women's freedom is constrained by men's control over their mobility, by sociocultural expectations that they are primarily responsible for all domestic work, and, in relation to this, by their uneven reproductive, productive, and community work burdens. Their restricted access to, control over, and ownership of land, credit, and information, as compared to men, gives them a disadvantage in meeting the conditions of formal group membership and leadership. However, [34] stated that, when women gain leadership positions, it helps them to build their self-confidence, exercise their political leadership, and gain respect from their male and female peers. There is also some evidence in the context of Ethiopia that, when there are women in leadership roles, there is a greater likelihood of other women participating in the organization [35].

Decision Making in Table 2 indicates that the proportion of women above the mean (38.29) for decision making as an index of empowerment is 53\%, which implies that they are empowered in decision making. Most women are not married and this could be the reason why they are actively involved in decision making. Women have been facing huge challenges in the area of decision making, firstly because of tradition and internal inferiority complex whereby 
there are not even sure if the decisions that they want to take will bear fruit and that will make them aversive in terms of decision making. When it comes to the sales of assets or crops to women, that will be the prerogative of women since most of them are not married The Grameen Bank in Bangladesh and other microcredit institutions are an exception because they give small loans to poor men and women. Access to these resources helps the women or men use their labour more effectively by enabling them to make decisions and adjustments in allocating resources under changing economic and climate conditions [21].

Table 2 indicates that $60.2 \%$ of women were below the mean of 291.61 , which implies that women are disempowered. According to [22], an individual is identified as empowered in '5DE'; the domains used as indices of empowerment if there are adequate achievements in four of the five domains or if they enjoy adequacy in some combination of the weighted indicators that sum to $80 \%$ or more, or if they have an adequacy score of 80 or above. Women are reflecting empowerment adequacy in only two indicators, leadership role and decision making, and disempowerment in three indicators.

Table 2: Empowerment indices among women on smallholder irrigation schemes.

\begin{tabular}{|l|l|l|l|l|l|l|}
\hline Income & $\begin{array}{l}\text { Use of } \\
\text { income }\end{array}$ & $\begin{array}{l}\text { Productive } \\
\text { capital }\end{array}$ & $\begin{array}{l}\text { Access to } \\
\text { credit }\end{array}$ & Leadership & Decision & $\begin{array}{l}\text { Total } \\
\text { empowerment } \\
\text { score }\end{array}$ \\
\hline $\mathrm{X}$ & 16.80 & 78.99 & 113.56 & 43.98 & 38.29 & 291.61 \\
\hline SD & 8.55 & 35.41 & 38.24 & 10.85 & 10.64 & 84.48 \\
\hline low & $47(56)$ & $50(60.2)$ & $50(60.2)$ & $43(51.8)$ & $44(53.0)$ & $50(60.2)$ \\
\hline high & $36(44)$ & $33(39.8)$ & $33(39.8)$ & $40(48.2)$ & $39(47.0)$ & $33(39.8)$ \\
\hline
\end{tabular}

\subsection{Determinants of women's empowerment}

The influence of the socio-economic characteristics and empowerment model was estimated using linear regression. The independent variables were significantly related with an $\mathrm{F}$ value of $1.94, \mathrm{p}<.05$. Also, an $\mathrm{R}$ value of 0.607 showed that there was a strong correlation between socio-economic characteristics and empowerment. The results further predicted $37 \%$ of the variation in socio-economic characteristics. Three out of sixteen independent variables were significant; with two variables being significant at $10 \%$ (expenditure and the use of drip irrigation system); while only one variable was significant at $5 \%$ (use of micro irrigation system). Significant determinants of empowerment were expenditure $(\mathrm{t}=1.68)$ and use of drip irrigation type $(t=1.71)$. These findings imply that, the lower the household expenditure, use of drip irrigation system and micro irrigation system, the more empowered are the farmers. However, age, marital status, number of dependants, household size, educational levels, non-farming activities, income, use of a central pivot system, use of a flood system, use of sprinklers, farm size and food security status do not have any correlation with empowerment of women farmers in irrigation farming. 
Table 3: Multiple regression analysis between socio-economic characteristics and empowerment.

\begin{tabular}{|l|l|l|l|l|l|}
\hline Variables & B & Std error & Beta & T & Sig \\
\hline Constant & 93.698 & 126.764 & & 0.739 & 0.463 \\
\hline Age & -0.129 & 0.551 & -0.032 & -0.233 & 0.816 \\
\hline Marital status & -0.958 & 8.828 & -0.015 & -0.108 & 0.914 \\
\hline Number of dependants & 3.198 & 2.721 & 0.148 & 1.175 & 0.244 \\
\hline Household size & -0.157 & 2.118 & -0.010 & -0.074 & 0.941 \\
\hline Education & -1.102 & 4.291 & -0.035 & -0.257 & 0.798 \\
\hline Labour source & 3.588 & 6.004 & 0.071 & 0.598 & 0.552 \\
\hline Non-farming activities & 8.563 & 15.677 & 0.059 & 0.546 & 0.587 \\
\hline $\begin{array}{l}\text { Central pivot irrigation } \\
\text { type }\end{array}$ & -6.734 & 24.291 & -0.069 & -0.277 & 0.783 \\
\hline Flood irrigation type & -27.368 & 31.547 & -0.121 & -0.868 & 0.389 \\
\hline Sprinkler irrigation type & 31.899 & 25.504 & 0.261 & 1.251 & 0.216 \\
\hline micro irrigation type & 54.515 & 24.269 & 0.383 & 2.246 & 0.028 \\
\hline Drip irrigation type & 15.489 & 9.062 & 0.301 & 1.709 & 0.092 \\
\hline Farm size & -3.718 & 17.197 & -0.027 & -0.216 & 0.830 \\
\hline R & 0.607 & & & & \\
\hline R square & 0.369 & & & & \\
\hline F & 1.936 & & & & \\
\hline P & 0.026 & & & & \\
\hline
\end{tabular}

\section{Conclusion}

The study has highlighted that many women have their livelihoods built around enterprises practised on the irrigation scheme and their access to livelihood assets for such livelihood activities were enhanced by the scheme. However, the indices for women's empowerment revealed that women were empowered in terms of leadership and decision making while disempowered in relation to use of income and access to productive capital. Factors identified as influencing the level of women's empowerment were expenditure and the use of drip irrigation. The study stressed the need to promote women's participation in decision-making for water management and also suggests ways in which women's access to water can be improved through equitable development.

\section{Acknowledgement}

This work was conducted through a project initiated, managed and funded by the Water Research Commission (WRC) entitled, "Empowerment of woman in rural areas through water use security and agricultural skills training for gender equity and poverty reduction in KwaZulu-Natal and North West Province (K5/2176)" as published in the WRC Knowledge Review (2012/13). 


\section{References}

[1] FAO. The State of Food and Agriculture, Women in Agriculture closing the gender gap for development. Food and Agriculture Organization of the United Nations, Rome, pp. 24-30, 2011.

[2] IFAD. Gender and water Securing water for improved rural livelihoods: The multiple-uses system approach. pp. 25-31, 2007.

[3] IPTRID. Poverty Reduction and Irrigated Agriculture (Rome: IPTRID/FAO). pp. 10-15, 1999.

[4] Backeberg G. R., Reforms of user Charges, Market Pricing and Management of Water Problem or Opportunity for irrigated agriculture. Irrigation and Drainage, (1). pp. 1-12, 2006.

[5] De Lange M, Small-scale irrigation in South Africa, WRC Report 5078/1/94 Pretoria: Water Research Commission. pp. 15-20, 1994.

[6] Bruwer J and Van Heerden P., Spotlight on irrigation development in the RSA, the Past, Present and Future, Water Commission, Pretoria. pp. 33-37, 1995.

[7] Backeberg G. R and Groenewald J.A., Lessons from the economic history of irrigation development for smallholder settlements in South Africa, Agrekon, 34(4). pp. 167-171, 1995.

[8] Bundy C., The rise and fall of the South African Peasantry, $2^{\text {nd }}$ edition Cape Town. pp. 32-37, 1988.

[9] Beinart W., Twentieth- Century South Africa, Oxford, Oxford University Press. pp. 65-70, 2001.

[10] Van Rooyen C, J, and Nene S., What can we learn from previous small farmer development strategies in South Africa? Agrekon, 34(2). pp. 325-331, 1996.

[11] Van Averbeke W., Denison J. and Mnkeni P.N.S. Smallholder irrigation schemes in South Africa: A review of knowledge generated by the Water Research Commission. pp. 27-35, 1998.

[12] Bembridge T.J. Guidelines for rehabilitation of small-scale farmer irrigation scheme in South Africa, WRC Report no 891/1/00 Water Research Commission, Pretoria. pp. 13-18, 2000.

[13] Schoengold K. and Zilberman D. The Economics of Water, Irrigation and Development, University of California, Berkeley. pp. 44-49, 2005.

[14] Ramazotti M., Readings in African customary water law, FAO, Rome. pp. 47-55, 1996.

[15] Jasper F.G.W. The new water legislation of Zimbabwe and South Africa: comparison of legal and institutional reform, Kluwer Academic Publisher, The Netherlands. pp. 36-40, 2001.

[16] Perret S., Water policy and smallholding irrigation scheme in South Africa: Water Policy, 4(3). pp. 282-300, 2002.

[17] Muller M. Transforming water law to achieve South Africa's development vision: a case study in national law. pp. 15-22, 2000. 
[18] DWAF. National Water Resource Strategy, draft 17, Possible outcomes of smallholders participation in water users association in South Africa. pp. 59-63, 2002.

[19] DWAF. Pricing Strategies of Raw Water charges, Government Gazette No 1353, Pretoria. pp. 27-35, 1999.

[20] FAO. Socio-economic impact of smallholder irrigation development in Zimbabwe. Sub Regional Office Harare. ISBN 0-7974-2083-5. pp. 47-53, 2000.

[21] IFAD Land and Water Governance Innovation Mainstreaming Initiative: Linking Land and Water Governance; Preparatory Phase. pp. 37-45, 2004.

[22] IFPRI Women's Empowerment in Agriculture Index, December 2, Discussion paper No 01240. pp. 4-10, 2012.

[23] Crowley E. Women's right to land and natural resources: Some implications for a human rights based approach, Food and Agriculture Organisation Rome pp 10-30, 1999.

[24] Akinbile L. A, Salimonu K. K, Yekinni O. T Farmers' participation in agroforestry practices in Ondo State, Nigeria. Research Journal of Applied Sciences, 2(3). pp. 229-232, 2007.

[25] Larson, K.H., and J. Kanyangwa. Women in market oriented agriculture. In A.P. Wood, S.A. Kean, J. T. Milimo, and D.M. Warren (eds.), The Dynamics of Agricultural Policy and Reform in Zambia. Ames, Iowa: Iowa State University Press. pp. 16-20, 1990.

[26] Maffioli, D., Gabrielli, G., and Sacco, P. Determinants of Female family headship in Sub-Saharan Africa. Provisional Paper presented at Union for African Population Studies English, Fifth African Population Conference Français, Arusha, Tanzania: 10-14, December. pp. 11-15, 2007.

[27] Judd, M. \& Dulnuan, J. Women's Legal and Customary Access to Land in the Philippines. World Bank, Washington, D.C. pp. 16-25, 2001.

[28] Adesope O.M, E.C. Matthews-Njoku, N.S. Oguzor and V.C. Ugwuja Effect of Socio-Economic Characteristics of Farmers on Their Adoption of Organic Farming Practices, Crop Production Technologies, Peeyush Sharma (Ed.). pp. 45-56, 2012.

[29] FAO, Water and Rural Poor Interventions for improving livelihoods in sub-Saharan Africa. pp. 55-59, 2008.

[30] Machete C.L., Mollel N.M., Ayisi K. Smallholder Irrigation NAD Agricultural Development in the Olifants River Basin of Limpopo Province: Management transfer, productivity, profitability food security issues, WRC Report No 1050/04. pp. 15-22, 2004.

[31] Lopi, B. Promoting women's full access to, and control over productive resources such as land, livestock, markets, credit, modern technology, formal employment, and a good quality of life in order to reduce the level of poverty among women. Southern African Research and Documentation Centre Women in Development Southern Africa Awareness (SARDC WIDSAA) pp. 7-11, 2004. 
[32] Van Koppen, B. A Gender Performance Indicator for Irrigation: Concepts, tools, and applications. Research Report 59, International Water Management Institute, Colombo, Sri Lanka. pp. 15-22, 2002.

[33] World Bank. Gender in Agriculture. Sourcebook. Washington, DC: World Bank. pp. 85-102, 2009.

[34] Gizachew, S. Women Economic Leadership through Honey Production Value Chain Development in Ethiopia. Presentation at ILRI Workshop on Gender and Market Oriented Agriculture, February 1, pp. 3-7, 2011.

[35] Oxfam International. Women's Collective Action: Unlocking the Potential of Agricultural Markets. Oxfam International Research Report. Oxford, UK: Oxfam International. pp. 5-9, 2013. 